\title{
Uranium in drinking water, naturally
}

Background: Uranium is a naturally occurring radionuclide in granite and other mineral deposits. It enters local water, air and food supplies in varying concentrations through leaching from natural deposits, its release in mill tailings, emissions from nuclear industry, dissolution in phosphate fertilizers and combustion of coal and other fuels. The average total daily uranium intake by a $70-\mathrm{kg}$ adult in Canada is estimated to be $2.6 \mu \mathrm{g}$, food accounting for $77 \%(2.0 \mu \mathrm{g})$ and water for most of the remainder. ${ }^{1}$ However, great regional variation in exposure levels has been reported. Uranium levels in samples of Canadian drinking water have ranged from nondetectable in certain treated municipal water samples to exceptionally high $(>700 \mu \mathrm{g} / \mathrm{L}$ ) in some private groundwater supplies. ${ }^{1}$

Natural uranium consists almost entirely of the uranium 238 isotope in its hexavalent state, which commonly associates with oxygen as the uranyl ion $\mathrm{UO}_{2}^{2+}$. It decays by both alpha (i.e., nucleus of a helium atom) and gamma (i.e., high-energy photon) emissions. Relative to other radionuclides, natural uranium has a low level of radioactivity because of its extremely long half-life (4.5 billion years).

Although there is a risk of radiological toxicity from orally ingested natural uranium, the principal health effects are chemical toxicity. Uranyl compounds have a high affinity for phosphate, carboxyl and hydroxyl groups and readily combine with proteins and nucleotides to form stable complexes. The skeleton and kidney are the primary sites of uranium accumulation; little is found in the liver. ${ }^{1}$

On average, $1 \%-2 \%$ of ingested uranium is absorbed in the gastrointestinal tract in adults. The absorbed uranium rapidly enters the bloodstream and forms a diffusible ionic uranyl hydrogen carbonate complex $\left(\mathrm{UO}_{2} \mathrm{HCO}_{3}{ }^{+}\right)$ in equilibrium with a nondif- fusible uranyl albumin complex. In the skeleton the uranyl ion replaces calcium in the hydroxyapatite complex of the bone crystal. Once equilibrium is attained in the skeleton, uranium is excreted in urine and feces. Under alkaline conditions, the uranyl hydrogen carbonate complex is stable and is excreted. When the $\mathrm{pH}$ drops, the complex dissociates and binds to the cellular proteins in the tubular wall. The half-life of uranium in the rat kidney is about 15 days, and considerably longer (300-5000 days) in the skeleton. ${ }^{1}$

Nephritis is the main chemically induced effect of uranium ingestion. There is some debate as to whether the segment of the nephron most at risk to injury is the proximal tubule or the glomerulus. Evidence from animal studies does not show carcinogenic effects from ingestion of uranium compounds. An associated risk of bone cancer has been inferred from the known risk due to exposure to radium 226, a radionuclide found in uranium ore, but the estimated excess risk is considered to be insignificant compared with background lifetime risk. Thus, the maximum acceptable concentration of uranium in drinking water in Canada is calculated on the basis of chemical not radiological toxicity criteria.

Clinical management: Signs of acute uranium toxicity include piloerection, significant weight loss and hemorrhages in the eyes, legs and nose. Barring a nuclear or occupational accident, a Canadian primary care physician will probably not encounter such a case in routine practice. Little information is available on the health effects of chronic exposure to environmental uranium. Human studies comparing communities with different uranium levels in their drinking water supplies have shown a trend toward elevated alkaline phosphatase levels and increased excretion of urinary $\beta_{2}$-microglobulin in people with increasing uranium exposure. ${ }^{2}$

Uranium exposure is not high on most primary care physicians' list of causes of early kidney disease, but it should be considered by physicians who serve communities with relatively high background levels of natural uranium. By routinely taking a thorough environmental history, ${ }^{3}$ including information on the patient's source of water supply and proximity to local industry, a physician will be in a position to suspect environmental exposure as a possible cause. The local public health unit or municipality should also have information on sources of potential local exposures.

Prevention: Studies in rats indicate that the lowest observed adverse effect level for degenerative changes in the proximal tubule is $60 \mu \mathrm{g} / \mathrm{kg}$ body weight per day (Box 1). After factoring in uncer-

\section{Tolerable daily intake (TDI) of uranium$$
\mathrm{TDI}=\frac{60 \mu \mathrm{g} / \mathrm{kg} \text { bw per day }}{100}=0.6 \mu \mathrm{g} / \mathrm{kg} \text { bw per day }
$$

where $60 \mu \mathrm{g} / \mathrm{kg}$ bw (body weight) per day is the lowest observed adverse effect level for adverse effects on the kidney in male rats, and 100 is the uncertainty factor $(\times 10$ for intraspecies variation and $\times 10$ for interspecies variation).

\section{Health-based guideline value (GV) of uranium} in drinking water

Based on the above TDI, a health-based GV may be determined as follows:

$$
\mathrm{GV}=\frac{0.6 \mu \mathrm{g} / \mathrm{kg} \text { bw per day } \times 70 \mathrm{~kg} \text { bw } \times 0.35}{1.5 \mathrm{~L} / \mathrm{d}}=10 \mu \mathrm{g} / \mathrm{L}
$$

where $0.6 \mu \mathrm{g} / \mathrm{kg}$ bw per day is the TDI, as derived above; $70 \mathrm{~kg}$ bw is the average weight of an adult; 0.35 is the proportion of daily intake of uranium allocated to drinking water (based on exposure level data given that the general population is generally exposed to drinking water containing uranium at concentrations below $10 \mu \mathrm{g} / \mathrm{L}) ;$ and $1.5 \mathrm{~L} / \mathrm{d}$ is the average daily consumption of drinking water by an adult.

Source: Guidelines for Canadian drinking water quality: supporting documentation - uranium (www.hc-sc.gc.ca/hecs-sesc/water /dwgsup.htm) 
tainty owing to intra- and interspecies variation and adjusting for additional exposure pathways and the average daily consumption of drinking water, the FederalProvincial-Territorial Committee on Drinking Water calculated the health-based guideline value of uranium in drinking water to be $10 \mu \mathrm{g} / \mathrm{L}$ (Box 1). In consideration of the water treatment costs associated with achieving this level and the low health risks associated with exceeding this level minimally, the committee has recommended an interim maximum acceptable concentration of $20 \mu \mathrm{g} / \mathrm{L}$. In most jurisdictions in Canada, suppliers of drinking water monitor water quality and comply with the recommended guidelines. $^{1}$

\section{Erica Weir CMAF}

I thank Brian Gibson, Associate Professor in the Department of Public Health Sciences, University of Toronto, for reviewing an earlier draft of this article.

\section{References}

1. Guidelines for Canadian drinking water quality: supporting documentation uranium. Ottawa: Federal-ProvincialTerritorial Committee on Drinking Water; 2001. Available: www.hc-sc.gc .ca/hecs-sesc/water/dwgsup.htm (accessed 2004 Feb 16).

2. Zamora ML, Tracy BL, Zielinski JM, Meyerhof DP, Moss MA. Chronic ingestion of uranium in drinking water: a study of kidney bioeffects in humans. Toxicol Sci 1998;43 (1):68-77.

3. Marshall L, Weir E, Abelsohn A, Sanborn $M$. Identifying and managing adverse environmental health effects: 1. Taking an exposure history. CMAf 2002;166(8):1049-55.

\section{Books Received}

Emanuel EJ, Crouch RA, Arras JD, Moreno JD, Grady C, editors. Ethical and regulatory aspects of clinical research: readings and commentary. Baltimore: Johns Hopkins University Press; 2004. 490 pp. US\$39.95 ISBN 0-8018-7813-6

Sam AH, Baker CR, Teo JTH, Hameed S. Medicine. Rapid series. Malden (MA): Blackwell; 2003. 326 pp. US\$29.95 ISBN 1-4051-0749-9.
Tunstall-Pedoe, editor. MONICA monograph and multimedia sourcebook: world's largest study of heart disease, stroke, risk factors, and population trends 1979-2002. Geneva: World Health Organization; 2003. 244 pp. US\$40.50 ISBN 92-4-156223-4

Yang KY, Graff LR, Caughey AB. Pharmacology. Blueprints Notes and Cases series. Malden (MA): Blackwell; 2003.
187 pp. US\$26.95 ISBN 1-40510348-5

Young VB, Kormos WA. Medicine, 3rd ed. Blueprints series. Malden (MA): Blackwell; 2003. 352 pp. $\$ 55.50$ ISBN 1-40510335-3

Wagner EK, Hewlett MJ. Basic virology, 2nd ed. Malden (MA): Blackwell; 2004. 440 pp. US\$94.95 ISBN 1-4051-0346-9 